\title{
First record of the genus Oedalea Meigen (Diptera: Hybotidae) from Vietnam, with description of a new species and a key to species of the Oriental Region
}

\author{
Первая находка рода Oedalea Meigen (Diptera: Hybotidae) \\ из Въетнама, с описанием нового вида \\ и кАючом дАя видов Ориентальной области
}

\author{
I.V. Shamshev \\ И.В. Шамшев
}

Laboratory of Insect Systematics, Zoological Institute, Russian Academy of Sciences, Universitetskaya nab. 1, St. Petersburg, 199034,
Russia. E-mail: shamshev@mail.ru
Зоологический институт РАН, Университетская наб. 1, С.-Петербург 199034, Россия.

KEYWORDS. Diptera, Hybotidae, Oedalea, Vietnam, new species.

КЛЮЧЕВЫЕ СЛОВА. Diptera, Hybotidae, Oedalea, Вьетнам, новый вид.

ABSTRACT. The genus Oedalea Meigen (Diptera, Hybotidae) is recorded for the first time from Vietnam, including a new species, $O$. vietnamensis sp.n. The species was collected in mountains of Lai Châu Province (north-western Vietnam). A key to species of Oedalea from the Oriental region is compiled.

РЕЗЮМЕ. Род Oedalea Meigen (Diptera, Hybotidae) впервые отмечается с территории Вьетнама, где он представлен единственным видом, O. vietnamensis sp.n. Новый вид был собран в горах провинции Лайтяу (северо-западный Вьетнам). Coставлена определительная таблица видов Oedalea Ориентальной области.

\section{Introduction}

Species of the genus Oedalea Meigen, 1820 are quite small predaceous flies with conspicuously long antennae, shiny black thorax and raptorial hind legs [Chvála, 1983]. The group currently includes 21 species, the majority of which are known from the Holarctic (Eurasia 14 species, North America 4 species). Three species of Oedalea were described from the Oriental Region (Myanmar, south of China) [Saigusa, Yang, 2003; Yang, Grootaert, 2006; Yang et al., 2007]. In addition, Plant [2015] notes some undescribed species of Oedalea from Thailand. All Oriental species of Oedalea occur in mountains preferring higher altitudes. Plant et al. [2011] consider that in the Oriental region
Oedalea probably has relatively recent Palaearctic origin. This paper provides the first record of Oedalea from Vietnam. The new species was collected from mountains (about $2000 \mathrm{~m}$ ) of the north-western part of the country (Lai Châu Province).

\section{Material and methods}

This study is based on Hybotidae material housed in Zoological Museum of Moscow State University, Moscow, Russia (ZMMU) and in the Zoological Institute of Russian Academy of Sciences, St. Petersburg, Russia (ZIN). Pinned, dried specimens were studied. To facilitate observations, the terminalia were macerated in cold $10 \% \mathrm{KOH}$, then put for a short period in $85 \%$ lactic acid and immersed in glycerine. The photo was produced using a Nikon SMZ 1500 stereomicroscope equipped with a Nikon D700 digital SLR camera and were aligned and stacked using the Helicon Focus 5.3.14 software. The holotype of the new species is housed in ZMMU.

\section{Taxonomic account}

Class Insecta Linnaeus, 1758

Order Diptera Linnaeus, 1758

Suborder Brachycera Macquart, 1834 Superfamily Empidoidea Latreille, 1804

How to cite this article: Shamshev I.V. 2020. First record of the genus Oedalea Meigen (Diptera: Hybotidae) from Vietnam, with description of a new species and a key to species of the Oriental Region // Russian Entomol. J. Vol.29. No.2. P.218-221. doi: 10.15298/rusentj.29.2.18 
Family Hybotidae Meigen, 1820

Subfamily Oedaleinae Chvála, 1983

Genus Oedalea Meigen, 1820

\section{Oedalea vietnamensis Shamshev, sp.n.}

Figs 1-4.

TYPE MATERIAL. Holotype, $\sigma^{\prime}$, labelled: VNM [= VIETNAM]: Lai Châu Prov., Hoàng Liên N.P., 22.34997 N, $103.76818^{\circ} \mathrm{E}$ 1947 m, 19.iv.2012, D. Gavryushin (ZMMU). Paratype, $1 \sigma^{7}$, same data as holotype (ZIN, dissected).

DIAGNOSIS. Antennae with postpedicel yellowish brown, postpedicel about 10X longer than wide, stylus slender, with seta-like apical segment, palpus black; thorax with yellowish stronger setae, six scutellars; legs extensively yellowish; wing uniformly faintly infuscate, $\mathrm{M}_{2}$ complete, pterostigma distinct, large; halter with darkened knob.

DESCRIPTION. Male (Fig. 1). Head black. Eyes holoptic, upper ommatidia enlarged. Frons represented by very small subtriangular space above antennae, subshiny, faintly pruinose. Face short, broad, shiny (including clypeus). Ocellar triangle subshiny, with 2 short dark setae. Occiput densely greyish pruinose; with rather sparse, black, moderately long setae on upper part (including postoculars) and some yellowish fine setae on lower part behind mouth-opening. Antenna with scape, postpedicel and stylus brownish, postpedicel yellowish brown to reddish brown; scape and pedicel with dark setulae (more numerous and distinct on pedicel); postpedicel very long, about 10x longer than wide near base; stylus very short, slender, with seta-like apical segment. Palpus short, black, with scattered black setulae. Proboscis brownish, labrum nearly half of eye height.

Thorax almost entirely black, only prothoracic sclerites (except antepronotum) and postalar tubercle reddish brown; extensively shiny, prothoracic sclerites, notopleuron narrowly along lower margin posteriorly, almost entirely laterotergite (except narrow space on lower part) and mediotergite (except two small lateral spots) tomentose; pale to yellowish (stronger setae) setose. Proepisternum bare on lower portion, with 2-3 short fine setae on upper portion opposite anterior spiracle. Antepronotum with several setulae on each side dorsally. Postpronotal lobe with several setulae. Mesonotum with 1 long strong notopleural (with 2 additional short fine and some minute setae), 1 moderately long and 1 minute postalars, 6 scutellars (two inner pairs very long); mesoscutum almost entirely covered with uniform setulae, multiserial acrostichals separated narrowly from dorsocentrals only before suture, 1 pair of very long dorsocentral prescutellars. Anterior and posterior spiracles brown.

Legs extensively yellowish (including coxae), only hind tibia (except extreme base and apex), apicis of basitarsi and entire tarsomeres 2-5 brownish; subshiny, mostly with incon-

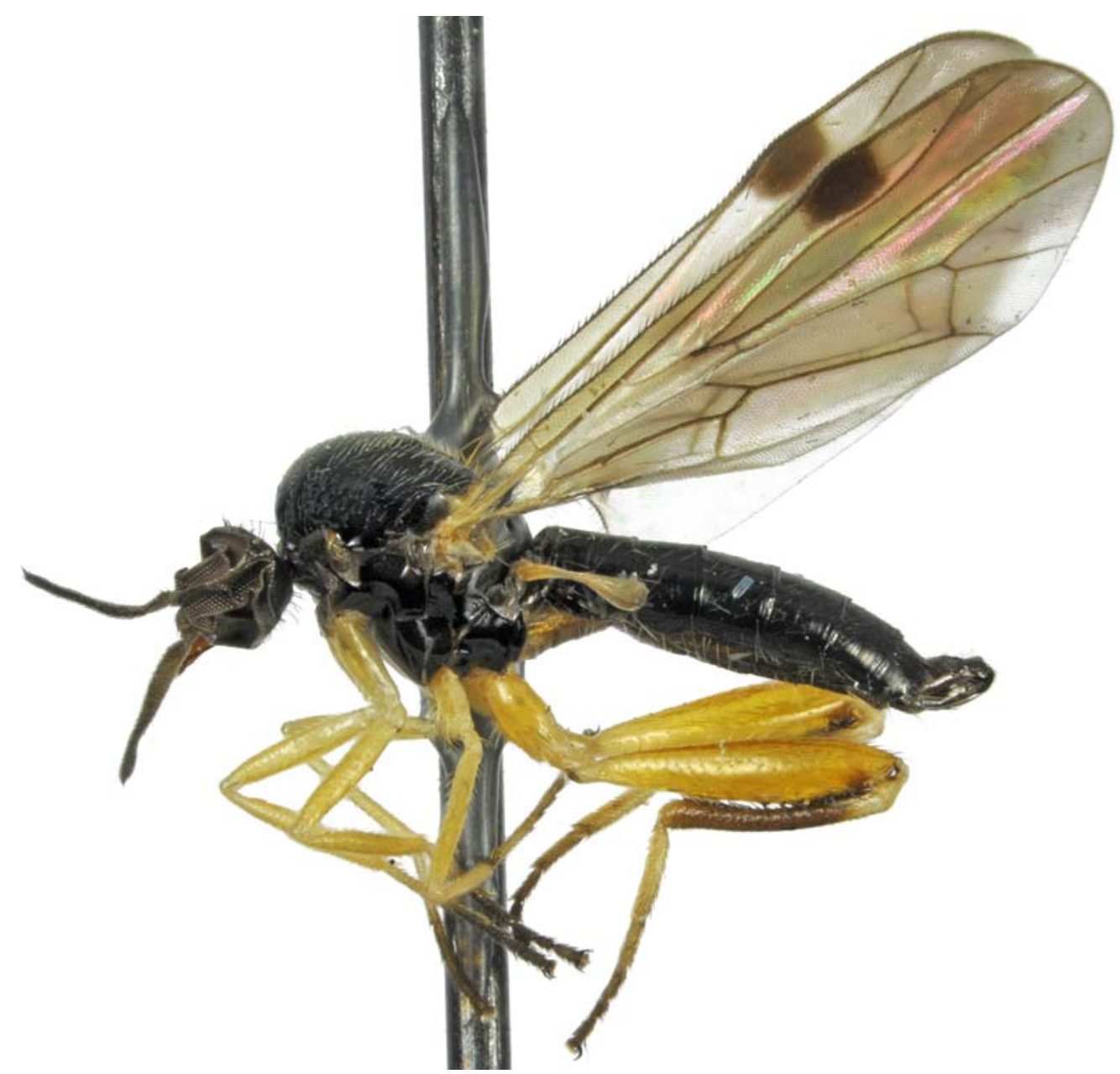

Fig. 1. Oedalea vietnamensis sp.n., male, habitus, holotype.

Рис. 1. Oedalea vietnamensis sp.n., самец, габитус, голотип. 
spicuous setation (except noted). Hind leg raptorial, with incrassate femur and geniculate, somewhat thickened and arcuate tibia. Coxae and trochanters with yellowish to pale setae. Femora with pale setae (except noted); fore and mid femora equally slender; hind femur with long fine setae posterodorsally and posteriorly on about basal $2 / 3$, numerous black spinelike setae beyond middle toward apex ventrally. Fore tibia almost uniformly somewhat thickened (except extreme base).

Wing membrane faintly brownish. Basal costal seta present, long, yellowish. Pterostigma distinct, brownish, subrectangular, covering about third distance between apicis of $\mathrm{R}_{1}$ and $\mathrm{R}_{2+3}$, lower margin almost reaching to $\mathrm{R}_{2+3}$. Veins brownish, mostly well sclerotised; $\mathrm{R}_{2+3}$ slightly sinuate apposite pterostigma; all branches of $\mathrm{M}$ reaching wing margin; $\mathrm{CuA}+\mathrm{CuP}$ (anal vein) evanescent toward wing margin, almost complete, reaching wing margin as fold. Cell dm very large and long, almost truncate, with very slightly produced apex. Anal lobe well-developed; axillary incision obtuse, closer to $90^{\circ}$. Squama pale yellow, pale fringed. Halter with darkened knob and yellow stem.

Abdomen with blackish brown tergites and brownish sternites, entirely shiny; covered with rather sparse yellowish to pale setae longer on tergites laterally.

Terminalia (Figs 2-4) small, elongate oval, brownish, subshiny. Cerci (Fig. 3) digitiform, of subequal length and width, slightly narrowed apically, covered with scattered, short, simple setae. Right epandrial lamella (Fig. 2) subrectangular (lateral view), with several very long setae along ventral margin; right surstylus broad, rather subglobular, mostly with simple short setae. Left epandrial lamella (Fig. 4) subrectangular, with several very long setae along ventral margin; left surstylus broad, somewhat concave apically, covered with mostly short simple setae, some longer setae along ventral margin.
MEASUREMENTS. Body $3.7 \mathrm{~mm}$, wing $3.5 \mathrm{~mm}$.

Female. Unknown.

DIFFERENTIAL DIAGNOSIS. Main differences between the new species and other Oriental species of Oedalea are indicated in the key given below. Among the Palaearctic species $O$. vietnamensis sp.n. resembles $O$. freyi Chvála, 1983, known only from the north of Fennoscandia. However, $O$. freyi can be readily distinguished from the new species by shorter, evenly conical postpedicel [Chvála, 1983: 167, Fig. 381], usually 8 scutellar setae (only one inner pair stronger) and uniformly yellowish halteres.

ETYMOLOGY. The epithet refers to the country of the origin of the new species.

DISTRIBUTION. Oriental: Vietnam.

Key to species of Oedalea Meigen from the Oriental REGION

1. Vein $M_{2}$ incomplete, not reaching wing margin; postpedicel brownish yellow (China: Guangdong)

O. nanlingensis Yang et Grootaert

- Vein $\mathrm{M}_{2}$ complete, reaching wing margin; postpedicel blackish

2. Palpus yellowish; halter pale (Myanmar) O. longicornis Frey

- Palpus black; halter at least with knob darkened ........ 3

3. Antennal stylus uniformly stout; pterostigma elongate oval, lower margin extending slightly beyond middle of distance between costa and $\mathrm{R}_{2+3}$ (China: Henan)

O. baiyunshanensis Saigusa et Yang Antennal stylus slender, with seta-like apical segment; pterostigma subrectangular, broader, lower margin almost touching to $\mathrm{R}_{2+3}$ (north-western Vietnam)

O. vietnamensis, sp.n.

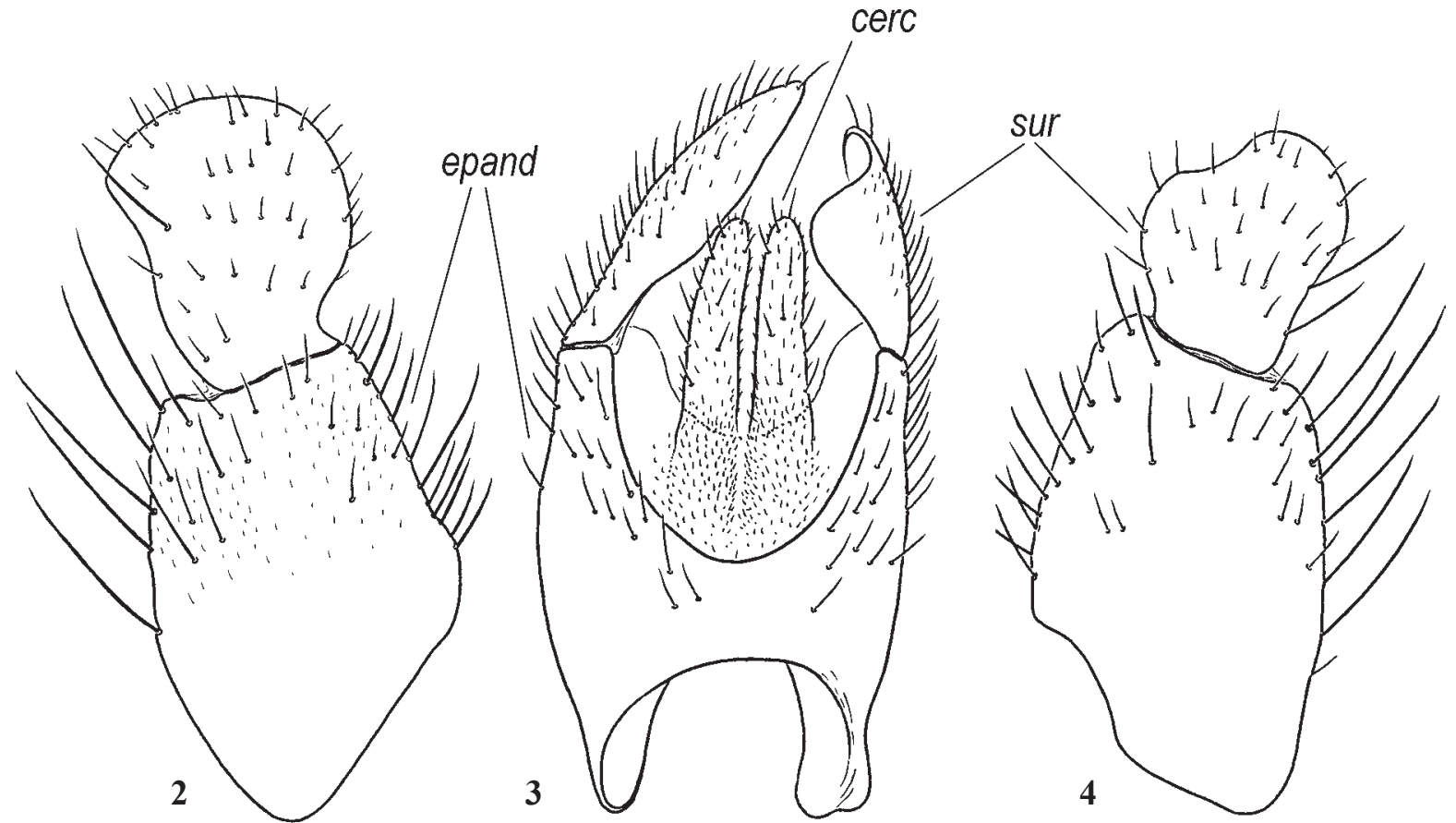

Figs 2-4. Oedalea vietnamensis sp.n., male: 2 - right epandrial lamella; 3 - cerci and epandrium; 4 - left epandrial lamella; 2,4 lateral view; 3 - dorsal view. Abbreviations: cerc - cercus; epand - epandrium; sur - surstylus.

Рис. 2-4. Oedalea vietnamensis sp.n., самец: 2 - правая лопасть эпандрия; 3 - церки и эпандрий; 4 - левая лопасть эпандрия; 2, 4 - сбоку; 3 - сбоку. Сокращения: cerc - церк; еpand - эпандрий; sur - сурстиль. 
Acknowledgments. I am indebted to Andrey Ozerov (ZMMU) for the loan of specimens used in this study. This study was performed within the frames of the Russian State Research Project no. AAAA-A19-119020690101- 6 and was supported by the Russian Foundation for Basic Research (grant no. 18-04-00354A).

\section{References}

Chvála M. 1983. The Empidoidea (Diptera) of Fennoscandia and Denmark. II. General Part. The Families Hybotidae, Atelestidae and Microphoridae//Fauna Entomologica Scandinavica. Vol.12. P.12-79.

Plant A.R. 2015. Diversity, distribution and community composition of Empididae, Hybotidae and Brachystomatidae (Insecta: Diptera) in Thailand how did they arise? // Research and Knowledge. Vol.1. P.1-14. https://doi.org/10.14456/randk.2015.1.

Plant A.R., Surin C., Saokhod R., Srisuka W. 2011. Higher taxon diversity, abundance and community structure of Empididae, Hybotidae and Brachystomatidae (Diptera: Empidoidea) in tropical forests results of mass-sampling in Thailand // Studia dipterologica. Vol.18. P.121-149. https://doi.org/10.1111/ j.1095-8312.2011.01771.x.

Saigusa T., Yang D. 2003. Empididae (Diptera) from Funiu Mountains, Henan, China (I) // Studia Dipterologica. Vol.9 (2002). P.519-543.

Yang D., Grootaert P. 2006. A new species of Oedalea Meigen from China, with a key to Asian species (Diptera, Hybotidae) // Deutsche Entomologische Zeitschrift. Vol.53. P.245-248. https://doi.org/10.1002/mmnd.200600020.

Yang D., Zhang K.Y., Yao G., Zhang J.H. 2007. World Catalog of Empididae (Insecta: Diptera). Beijing: China Agricultural University Press. 599 pp 